Potravinarstvo Slovak Journal of Food Sciences

vol. 15, 2021, p. 521-527

https://doi.org/10.5219/1534

Received: 21 December 2021. Accepted: 14 June 2021.

Available online: 28 June 2021 at www.potravinarstvo.com

(C) 2021 Potravinarstvo Slovak Journal of Food Sciences, License: CC BY 4.0

ISSN 1337-0960 (online)

\title{
THE CARCASS AND MEAT QUALITY CHARACTERISTICS OF J APANESE QUAIL FED A DIET SUPPLEMENTED WITH POWDERED LACTUCA SERIOLA LEAVES
}

\author{
Azad Sabow, Nazim Abdulla, Bestoon Ahmed
}

\begin{abstract}
The present study was aimed to evaluate the effect of dietary supplementation with Lactuca serriola leaves on growth performance, carcass characteristics, meat quality, and its antioxidant stability of Japanese quails. A total of eighty growing quails (1-week old) were distributed into 2 equal groups consisting of 40 birds ( 5 replicates of 8 birds each). The first group was fed a basal diet without Lactuca serriola leaves ( 0 g. $\mathrm{kg}^{-1}$ diet) and the second group received diets containing 20 g.kg ${ }^{-1}$ Lactuca serriola leaves. At age of 6 weeks, quails were slaughtered for meat and carcass examinations. The growth performance for the quails fed with Lactuca serriola leaves diet was similar to that of a control group. Carcass measurements, physical properties, and chemical composition of quail breast meat did not differ between the control and experimental group. However, the inclusion of Lactuca serriola leaves significantly increased the omega-3 polyunsaturated fatty acid content and improved breast meat lipid stability during postmortem refrigerated storage compared to the control diet. In conclusion, dietary supplementation of Lactuca serriola leaves can improve the performance of Japanese quail enrich its meat with an omega-3 polyunsaturated fatty acid, and reduce lipid oxidation during storage.
\end{abstract}

Keywords: growth; Lactuca serriola; meat traits; polyunsaturated fatty acid; quail

\section{INTRODUCTION}

In recent years, products of different species of poultry are marketed including quail products. Japanese quail is the main species of poultry whose meat is commonly demanded everywhere in the world, especially in America, Europe, and Asian nations (Partovi and Seifi, 2018). Nowadays, a major concern of poultry producers is to optimize the produced meat both qualitatively and quantitatively (Abdulla et al., 2017). Consequently, many recent studies have been represented herbs and spices as efficient and safe feed additives to improve poultry health as well as the rate of growth (Adegoke et al., 2018; Rasul, 2020; Reda et al., 2020). Additionally, the active molecules in herbs and spices or their oils can prevent meat oxidation that negatively affects the meat's organoleptic properties and also abates its nutritional value (Reda et al., 2020). Lipid oxidation is a limiting factor, which determines the safety and shelf-life of meat. It is considered a major cause of non-microbial meat spoilage, specifically under pro-oxidative conditions such as storage during refrigeration and frozen (Sabow et al., 2016).

Lactuca serriola L. (Compositae) is an herbaceous species widely grown in Europe, India, Pakistan, India, and Middle Eastern countries. The plant is used in a medicinal application that is the old practice of human history (Vargas-Sánchez et al., 2019). Research has demonstrated that Lactuca serriola contains lactic acids and $\beta$ - carotene. It is also a rich source of almost all vitamins and contains a high amount of calcium, zinc, and iron (Janbaz et al., 2013). Lactuca serriola contains phenolic compounds that help to enhance its antioxidants capacity. The antioxidant effect of Lactuca serriola is explained by its phenolic compounds including cichoric acid, alkamides, caffeic acid, and chlorogenic acid (Nabavi et al., 2012).

Early investigations studied the effects of Lactuca serriola as pharmacological properties in humans, rabbits, and mice such as antitumor, antiviral, antimicrobial, antiinflammatory, hypotensive, and antioxidant (Al-Marzoqi, Hussein and Al-Khafaji, 2015; Ahangarpour, Oroojan and Radan, 2014; Janbaz et al., 2013). Investigations regarding the inclusion of powdered Lactuca serriola leave in Japanese quail diets and its effects on carcass quality were not found. It is hypothesized that the dietary addition of Lactuca serriola is expected to exert beneficial effects on the performance quality of carcass and meat of quail. Therefore, the present study was designed to assess the impacts of dietary inclusion of Lactuca serriola 
leaves on performances, carcass quality, and oxidative stability of Japanese quail meat.

\section{Scientific hypothesis}

The results of the current study will provide new knowledge and useful information about the Lactuca serriola plant and its antioxidant activity, which will give a wide range of possibilities for employing this plant as a source to improve the quality of carcass and oxidation stability of poultry meat.

\section{MATERIAL AND METHODOLOGY}

We assessed meat quality characteristics of Japanese quail fed a diet supplemented with or without Lactuca seriola leaves. A total of 80 male growing Japanese quails (one-week-old) with an average weight of $11.667 \pm 0.21 \mathrm{~g}$ were obtained from a commercial farm (Quail Farming, Qushtapa, Erbil-Kurdistan Region of Iraq) and randomly distributed into 2 groups, each of which included 5 replicates of 8 birds. Birds were housed in conventional type cages $(90 \times 40 \times 40 \mathrm{~cm})$ with feed and fresh water provided ad libitum. This study lasted until the $6^{\text {th }}$ week of age. The dietary treatments were as follows: (1) basal diet without supplementation (0 g. $\mathrm{kg}^{-1}$ diet) and (2) basal diet +20 g Lactuca serriola per $1 \mathrm{~kg}$. The aerial parts of Lactuca serriola were collected from the botanical garden of Erbil city (Kurdistan Region, Iraq) in the year 2019. The plant was identified based on taxonomy from the College of agriculture engineering and science. The leaves were washed thoroughly in distilled water and the surface water was removed by air drying under shade. The leaves were subsequently dried in a hot air oven (CS101beb ventilation oven, Chonping Sida instrument, China) at $40{ }^{\circ} \mathrm{C}$ for $48 \mathrm{~h}$, ground into a fine powder and stored at $4{ }^{\circ} \mathrm{C}$ in dark containers until using as feed additive. On the day of manufacture, Lactuca serriola leaves powder was added to a $1 \mathrm{~kg}$ sample of basal feed-in a Univex Mixer (SRM20 Counter Mixer, USA) and mixed for 5 minutes before being remixed with the allotted feed. The chemical compositions of fresh leaves were as following: $93.7 \%$ moisture, $1.4 \%$ protein, $0.4 \%$ fat, $1.1 \%$ fiber, $2.2 \%$ carbohydrate and $1.2 \%$ ash.

The composition of the basal diet (Table 1) was formulated to meet the quails' requirements based on the guidelines provided by the National Research Council (1994). Birds were exposed to $24 \mathrm{~h}$ of lighting with the temperature kept at 20 to $24^{\circ} \mathrm{C}$ throughout the experiment.

\section{Chemical}

All the chemicals used were of analytical grade and were purchased from Sigma-Aldrich (St. Louis, MO, USA).

\section{Growth performance}

At six weeks of age, individual body weight was recorded. Also, feed intake was recorded during the experimental periods on a replicate basis to estimate feed conversion ratio (FCR $=\mathrm{g}$ feed per $\mathrm{g}$ gain $)$.

\section{Slaughtering procedures and carcass measurements}

At the end of the experiment at 6 weeks of age, ten quails from each treatment were randomly selected, weighed, and slaughtered following the halal slaughter procedure. The halal slaughtering method was carried out by cutting the neck, severing both carotid arteries and jugular veins without decapitating the head during the process. Upon slaughter, carcasses were immediately taken to the laboratory for carcass examinations. Dressed carcasses were chilled at $4{ }^{\circ} \mathrm{C}$ for $24 \mathrm{~h}$ and reweighed (cold carcass weight; CCW). The dressing out the percentage of the carcass was determined as the proportion of CCW to the slaughter weight.

\section{Physical analyses of quail breast meat}

For meat quality characteristics, the breast muscle was separated into two parts. The first part was properly labeled, vacuum packaged, and stored at $4{ }^{\circ} \mathrm{C}$ for determination of drip loss. The second breast portion was used for other meat quality measures including $\mathrm{pH}$, cooking loss, and tenderness. The $\mathrm{pH}$ of meat was recorded immediately after $24 \mathrm{~h}$ postmortem on the breast muscle using a portable $\mathrm{pH}$ meter (HANNA ${ }^{\circledR}$ instruments, Woonsocket, USA) after calibration using two buffers of $\mathrm{pH} 4.0$ and 7.0. Cooking loss and tenderness of the breast samples were measured using the procedure described by Sabow (2020). To measure cooking loss, the meat samples were cooked at $80{ }^{\circ} \mathrm{C}$ in a pre-heated water bath (HAAKE ${ }^{\circledR}$ instruments, Woonsocket, USA) for another $10 \mathrm{~min}$ once the internal temperature of the samples has reached $78{ }^{\circ} \mathrm{C}$. After cooking loss determination, the cooked meat samples were collected and used to determine tenderness using the Volodkovitch bite jaw attached to a Brookfield Texture Analyzers (CT3 ${ }^{\mathrm{TM}}$, Middleborough, USA). For each sample, a block of $1 \mathrm{~cm}$ (height) $\times 1 \mathrm{~cm}$ (width) $\times 2 \mathrm{~cm}$ (length) was cut parallel to the direction of the muscle fibers and sheared vertically in the middle to the longitudinal direction of the muscle fibers. The sheer force values were represented as the average peak positive peak force $(\mathrm{kg})$.

\section{Chemical analysis of quail breast meat}

The proximate composition of the breast meat samples was analyzed using the procedure provided by the Association of Analytical Chemists according to AOAC (Horwitz, 2000). Moisture was determined by drying $1 \mathrm{~g}$ of meat in an oven (CS101-beb ventilation oven, Chonping Sida instrument, China) at $75^{\circ} \mathrm{C}$ until a constant weight was obtained. Crude protein was measured by the Kjeldahl method (VAPODEST® ${ }^{\circledR}$ 500, Gerhardt, Germany). The crude protein was obtained as $6.25 \times$ nitrogen $\%$. The fat content of the meat was determined by the Soxhlet extraction method (Classic Soxhlet Apparatus, Gerhardt, Germany) using petroleum ether. The Ash content of the meat was estimated by burning the sample in a muffle furnace (Heraeus KR 170E, Germany) at $550^{\circ} \mathrm{C}$ for $3 \mathrm{~h}$.

\section{Oxidative stability of quail breast meat}

The Thiobarbituric acid reactive substances (TBARS) value of the breast meat after 1 and 7 days of refrigerated storage was determined in duplicate according to the method described by Aminzade Karami and Lotfi (2012). Briefly, $5 \mathrm{~g}$ of meat was homogenized with $48 \mathrm{~mL}$ of distilled water and $1.25 \mathrm{~mL}$ of $4 \mathrm{~N} \mathrm{HCl}$ for $2 \mathrm{~min}$. The mixture was distilled until $25 \mathrm{~mL}$ was obtained. After filtration, $2.5 \mathrm{~mL}$ of the distillate was mixed with $2.5 \mathrm{~mL}$ of Thiobarbituric acid reagent (15\% trichloroacetic acid, 
$0.375 \%$ thiobarbituric acid). The samples were incubated in a water bath at $100{ }^{\circ} \mathrm{C}$ for $35 \mathrm{~min}$ and then cooled under running tap water for $10 \mathrm{~min}$. The absorbance was measured at $538 \mathrm{~nm}$ against a blank with a spectronic ${ }^{\circledR} 20$ GENESYSTM spectrophotometer (Spectronic Instruments, USA). The TBARS values were obtained by multiplying optical density by 7.843 and expressed as malondialdehyde (MDA) per kg meat.

\section{Statistical Analysis}

The obtained data were subjected to one-way analysis of variance (ANOVA) in the general linear model using Statistical Analysis System package (SAS) version 9.1 software (SAS Institute Inc., Cary, NC, USA). For comparison of TBARS values in day 1 and 7 postmortems, the parametric repeated measures ANOVA test were performed, and interaction between treatment groups and sampling times are calculated but were not statistically different. Differences between groups were tested with an independent sample T-test and the significance was established at a level of $0.05(p<0.05)$.

\section{RESULTS AND DISCUSSION \\ Quail growth performance and carcass measurements}

The effect of diet supplementation with Lactuca serriola leaves on the total final body, feed intake weight, feed conversion ratio, carcass weight, dressing percentage of Japanese quail at 6 weeks of age are given in Table 2 . The inclusion of Lactuca serriola leaves in the quail diet led

to improve final body weight, feed intake, and feed conversion ratio compared to the control treatment, although the values were not statistically significant. Lactuca serriola plant through its content of antioxidants plays a significant role in increase the activities of a digestive enzyme such as amylases, proteases, and lipases. Generally, stimulation of the function of pancreatic enzymes leads to promote the synthesis of bile acids in the liver and their secretion in the bile, which has a beneficial effect on digestion and absorption as well as growth stimulation. Adegoke et al. (2018) reported that growth performance is affected by active compounds of plant-derived supplements used in poultry nutrition. The present findings are in agreement with the findings of Partovi and Seifi (2018) who found no significant difference in better growth performance results $(p>0.05)$ of Japanese quail fed medicinal herb as feed additives compared with the control group.

The quail carcass traits such as carcass weight and carcass yield are an indicator of their significant efficiency and the ability for meat production (Nasr, Ali and Hussein, 2017; Sabow, 2020) which could be influenced by the inclusion of natural plants used in poultry nutrition (Vargas-Sánchez et al., 2019). Some investigations have demonstrated the positive effect of adding natural herbs to the nutrition on poultry carcass measurements (Ghazaghi Mehri and Bagherzadeh-Kasmani, 2014; Nosrati et al., 2017), while others have not emphasized such effects (Abd El-Hack, Alagawany and Abdelnour,
2019). In the present study, dietary supplementation of Lactuca serriola leaves did not affect $(p>0.05)$ on the carcass weight and carcass yield (Table 2). In agreement with the current findings, Reda et al. (2020) found no significant effect of plant supplements feeding on the carcass traits of quails. In growing rabbits, Abd El-Hack, Alagawany and Abdelnour (2019) also reported that there was no significant difference in carcass measurements between animals fed diets containing herbal natural feed additives and those in the control animals.

\section{Physical properties and chemical composition of quail breast meat}

As shown in Table 3, the values of drip loss, cooking loss, and shear force for both experimental and control diets were not significantly different. This observation may be because of the similarity in the ultimate $\mathrm{pH}$ of breast meat which was 6.26 and 6.12 for quails fed control and experimental diet, respectively. The ultimate $\mathrm{pH}$ is a significant factor that influences the physicochemical attributes of meat (Chan, Omana and Betti, 2011; Sabow, Haddad and Nakyinsige, 2020). The results of the current study agreed with Partovi and Seifi (2018) who detected no statistical influence of adding a natural plant to the quail diet on meat physical traits.

The inclusion of natural ingredients such as medicinal herbs and plants in the poultry diet effects on the nutritional composition of meat is unclear. The present results of proximate compositions of breast meat are not significantly different $(p>0.05)$ between the experimental and control group. This finding is consistent with that of Partovi and Seifi (2018) who clarified those herbal dietary supplements for Japanese quail diets had not affirmative effects in protein and fat values. Also, Shirzadegan and Falahpour (2014) found that meat samples of broiler chickens supplemented with dietary mixture medicinal herb has similar moisture, protein, and fat as compared to meat samples of the control group.

\section{Polyunsaturated fatty acids of quail breast meat}

Polyunsaturated fatty acids are widely taken into account to have a more beneficial biological effect (Givens, Kliem and Gibbs, 2006; Gecgel et al., 2015). The effects of dietary treatments on polyunsaturated fatty acids (PUFA) of quail breast meat are given in Table 4. Although n-6 PUFA concentration did not differ between dietary treatments, feeding Lactuca serriola leaves diet improved significantly the total n-3 fatty acids of quail breast meat. The ratio of $n-6$ to $n-3$ PUFA was significantly lower in the breast muscles of quails fed on Lactuca serriola leaves as a result of their relatively high total n-3 PUFA concentrations. The n-6 to n-3 ratio is generally used as an index to assess the nutritional value of dietary fat that has particular relevance to human health (Young, 2009; Valencak et al., 2015). The recent ratio of $n-6$ to $n-3$ fatty acids in the diets of North American adults should be in a range of 10:1 to 50:1, thus the ratios detected in the current study fall within this range. 
Table 1 Composition of the experimental diet.

\begin{tabular}{|c|c|}
\hline Ingredient & g.kg-1 diet \\
\hline Wheat & 175.0 \\
\hline Corn & 200.0 \\
\hline Wheat flour & 250.0 \\
\hline Soya bean meal & 290.0 \\
\hline Protein concentrate (fish meal concentrate) & 50.0 \\
\hline di - calcium phosphate & 6.0 \\
\hline Methionine & 0.9 \\
\hline Lysine & 0.5 \\
\hline Choline chloride & 0.5 \\
\hline Salt & 0.9 \\
\hline Soya bean oil & 13.0 \\
\hline Feed toxic & 1.0 \\
\hline Limestone & 10.0 \\
\hline Vitamins premix ${ }^{1}$ & 0.7 \\
\hline Feed sterilizes & 1.0 \\
\hline Anticoccidial & 0.5 \\
\hline \multicolumn{2}{|l|}{ Analyzed feed composition } \\
\hline Crud protein (g.kg-1) & 230.0 \\
\hline Energy metabolism (MJ.kg $\left.{ }^{-1}\right)$ & 12.6 \\
\hline
\end{tabular}

Table 2 Growth performance and carcass traits of growing Japanese quail as affected by graded levels Lactuca serriola leaves.

\begin{tabular}{|c|c|c|c|c|}
\hline \multirow[t]{2}{*}{ Items } & \multicolumn{2}{|c|}{$\begin{array}{c}\begin{array}{c}\text { Lactuca serriola leaves level (g.kg } \\
\text { diet) }\end{array} \\
\end{array}$} & \multirow[t]{2}{*}{ SEM } & \multirow[t]{2}{*}{$p$ value } \\
\hline & $\mathbf{0}$ & 20 & & \\
\hline Live body weight (g) & 141.168 & 153.792 & 0.24 & 0.198 \\
\hline Total feed intake (g per day) & 13.966 & 14.608 & 0.77 & 0.332 \\
\hline Feed conversion ratio (g feed per g gain) & 3.463 & 3.325 & 0.15 & 0.851 \\
\hline Slaughter body weight (g) & 145.801 & 160.798 & 5.96 & 0.063 \\
\hline Carcass weight (g) & 91.457 & 100.412 & 3.47 & 0.087 \\
\hline Dressing (\%) & 62.717 & 62.446 & 1.27 & 0.772 \\
\hline
\end{tabular}

Note: SEM = Standard Error of the Means.

Table 3 Physical characteristics and chemical composition of breast meat of growing Japanese quail as affected by graded levels of Lactuca serriola leaves.

\begin{tabular}{|c|c|c|c|c|}
\hline \multirow{2}{*}{ Items } & \multicolumn{2}{|c|}{ Lactuca serriola leaves level (g.kg-1 diet) } & \multirow{2}{*}{ SEM } & \multirow{2}{*}{$p$ value } \\
\hline & $\mathbf{0}$ & 20 & & \\
\hline $\mathrm{pH}$ & 6.260 & 6.120 & 0.07 & 0.288 \\
\hline Drip loss (\%) & 1.471 & 1.261 & 0.13 & 0.352 \\
\hline Cooking loss (\%) & 17.302 & 16.619 & 0.91 & 0.503 \\
\hline Shear force (kg) & 0.916 & 0.872 & 0.07 & 0.604 \\
\hline Moisture (\%) & 72.453 & 71.712 & 0.71 & 0.476 \\
\hline Protein (\%) & 20.539 & 21.110 & 0.59 & 0.516 \\
\hline Fat $(\%)$ & 5.926 & 6.059 & 0.48 & 0.853 \\
\hline Ash (\%) & 1.081 & 1.117 & 0.05 & 0.651 \\
\hline
\end{tabular}

Note: SEM = Standard Error of the Means. 


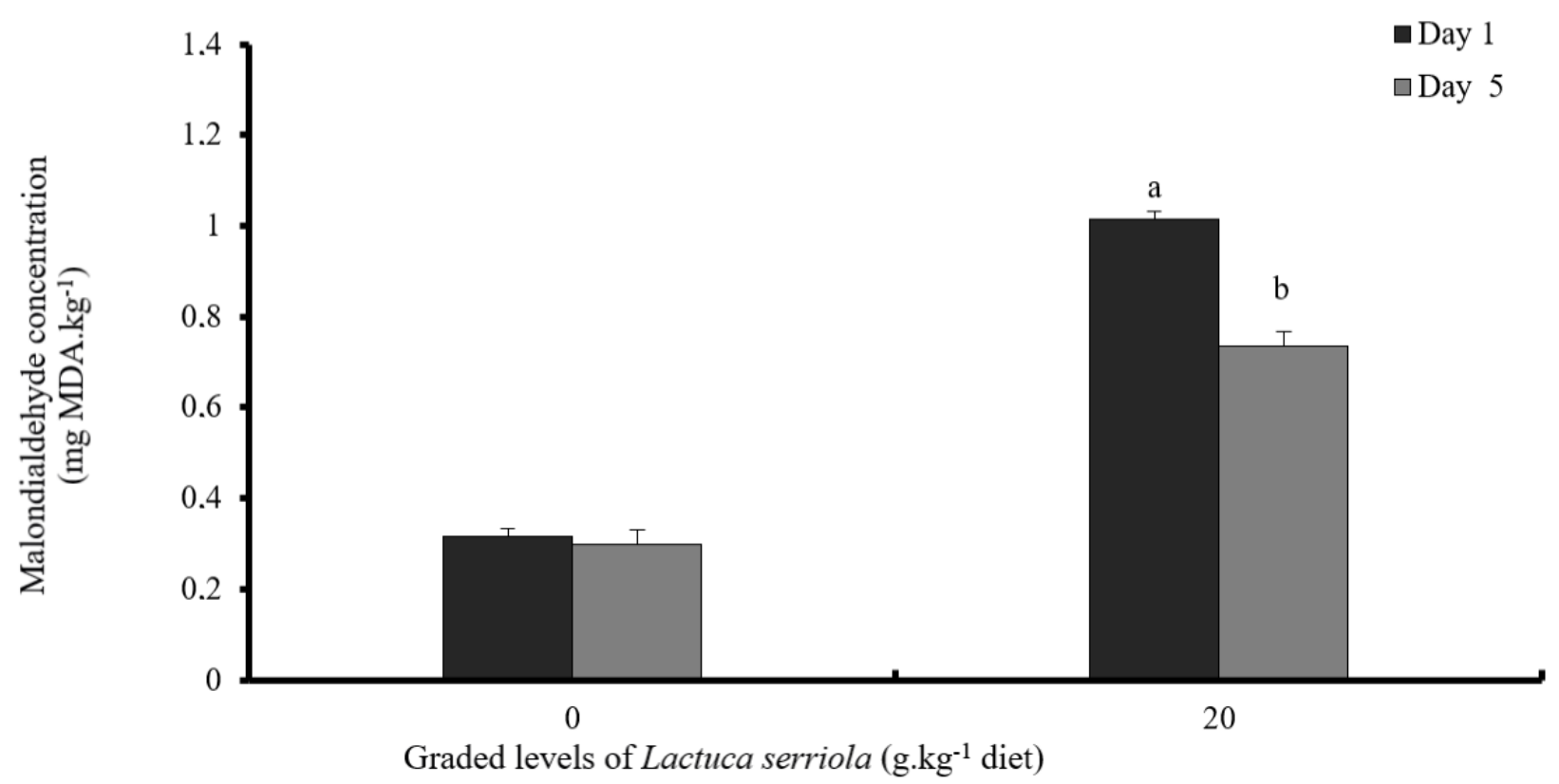

Figure 1 Lipid stability of breast meat obtained from growing Japanese quail fed dietary Lactuca serriola leaves supplementation.

Note: ${ }^{\mathrm{a}, \mathrm{b}}$ Means with different letters are significantly different at $p<0.05$.

Table 4 Polyunsaturated fatty acids of breast meat of growing Japanese quail as affected by graded levels of Lactuca serriola leaves.

\begin{tabular}{lcccc}
\hline \multirow{2}{*}{ Items } & \multicolumn{2}{c}{ Lactuca serriola leaves level (g.kg-1 diet) } & \multirow{2}{*}{ SEM } & \multirow{2}{*}{$\boldsymbol{p}$ value } \\
\cline { 2 - 4 } & $\mathbf{0}$ & $\mathbf{2 0}$ & $0.874^{\mathrm{b}}$ & 0.03 \\
\hline Total n-3 PUFA (\%) & $0.629^{\mathrm{b}}$ & 0.019 \\
Total n-6 PUFA (\%) & 14.882 & 15.341 & 0.96 & 0.308 \\
n6/n3 ratio & $24.031^{\mathrm{a}}$ & $18.457^{\mathrm{b}}$ & 2.11 & 0.028 \\
\hline
\end{tabular}

Note: ${ }^{\mathrm{a}, \mathrm{b}}$ Means within the same row with different letters are significantly different at $p<0.05$.

Total n-3 PUFA = Total omega-3 poly unsaturated fatty acids.

Total n-6 PUFA = Total omega-6 poly unsaturated fatty acids.

SEM $=$ Standard Error of the Means.

\section{Lipid oxidation of quail breast meat}

Lipid oxidation is the main evidence of the quality deterioration of meat by reducing shelf life during refrigeration storage (Estévez, 2015; Sabow, 2020). Therefore, the shelf-life of fresh meat is limited to a few days during storage at refrigeration temperature unless preservation methods are used. Natural ingredients such as medicinal herbs and plants which have been used in the poultry, diet have been thought to provide beneficial compounds with antioxidant activity, which might be beneficial for shelf-life extension or meat quality maintenance (Krishnan et al., 2014; Alagawany, Ashour and Reda, 2016; Aziz and Karboune, 2018). The results of the lipid stability of breast meat during the first five days postmortem are given in Figure 1 . At $1^{\text {st }}$ day postmortem, no significant difference was observed in lipid oxidation of breast meat between experimental and control diet. However, the MDA values of groups fed with Lactuca serriola leaves were significantly lower than those in the control, which indicated a good antioxidant capable of removing free radicals. Furthermore, the ability of Lactuca serriola leaves to reduce breast muscle lipid oxidation could be due to its total n-3 polyunsaturated fatty acids content as reported by Sabow, Haddad and Nakyinsige (2020) who attributed that lipid oxidation is significantly influenced by muscle $n-3$ polyunsaturated fatty acids and muscle with high n-3 polyunsaturated fatty acids gives lower malondialdehyde values than those with low n-3 polyunsaturated fatty acids. The current data are following those of Ghazaghi Mehri and BagherzadehKasmani (2014) who observed that dietary inclusion of medicinal herbs decreased the lipid oxidation of quail 
meat. Regardless of dietary groups, the MDA concentration of all breast meat samples kept at refrigerator temperature for 5 days increased $(p<0.05)$ compared to that of refrigerated storage samples on day 1 . These observations are consistent with those of Sabow, Haddad and Nakyinsige (2020) and Partovi and Seifi (2018) who observed that lipid oxidation values of quail breast meat significantly increased with storage time at refrigerator temperature.

\section{CONCLUSION}

The results of the current study indicated that dietary supplementation of Lactuca serriola increased the omega3 polyunsaturated fatty acids content and improved lipid stability during postmortem aging of growing Japanese quails. Further research is required to investigate the impact of dietary Lactuca serriola leaves on performance, some blood parameters, and morphology with microbial populations of the small intestine in quail (Coturnix coturnix japonica).

\section{REFERENCES}

Abd El-Hack, M. E., Alagawany, M., Abdelnour, S. 2019. Responses of growing rabbits to supplementing diet with a mixture of black and red pepper oils as a natural growth promoter. Journal of Animal Physiology and Animal Nutrition, vol. 103, no. 2, p. 509-517. https://doi.org/10.1111/jpn.13045

Abdulla, N. R., Mohd Zamri, A. N., Sabow, A. B., Kareem, K. Y., Nurhazirah, S., Ling, F. H., Sazili, A. Q., Loh, T. C. 2017. Physico-chemical properties of breast muscle in broiler chickens fed probiotics, antibiotics or antibiotic-probiotic mix. Journal of Applied Animal Research, vol. 45, no. 1, p. 64-70. https://doi.org/10.1080/09712119.2015.1124330

Adegoke, A. V., Abimbola, M. A., Sanwo, K. A., Egbeyale, L. T., Abiona, J. A., Oso, A. O., Iposu, S. O. 2018. Performance and blood biochemistry profile of broiler chickens fed dietary turmeric (Curcuma longa) powder and cayenne pepper (Capsicum frutescens) powders as antioxidants. Veterinary and Animal Science, vol. 6, p. 95102. https://doi.org/10.1016/j.vas.2018.07.005

Ahangarpour, A., Oroojan, A. A., Radan, M. 2014. Effect of aqueous and hydro-alcoholic extracts of lettuce (Lactuca sativa) seed on testosterone level and spermatogenesis in NMRI mice. International Journal of Reproductive BioMedicine, vol. 12, no. 1 , p. 65-72.

Alagawany, M., Ashour, E. A., Reda, F. M. 2016. 14. Effect of Dietary Supplementation of garlic (Allium sativum) and Turmeric (Curcuma longa) on growth performance, carcass traits, blood profile and oxidative status in growing rabbits. Annals of Animal Science, vol. 16, no. 2, p. 489-505. https://doi.org/10.1515/aoas-2015-0079

Al-Marzoqi, A. H., Hussein, H. J., Al-Khafaji, N. S. 2015. Antibacterial activity of the crude phenolic, alkaloid and terpenoid compounds extracts of Lactuca serriola L. on human pathogenic bacteria. Chemistry and Materials Research, vol. 7, no. 1, p. 8-10.

Aminzade, B., Karami, B., Lotfi, E. 2012. Meat quality characteristics in Japanese quails fed with Mentha piperita plant. Animal Biology and Animal Husbandry, vol. 4, no. 1, p. 20-23. Available

at: http://www.abah.bioflux.com.ro/docs/2012.20-23.pdf

Aziz, M., Karboune, S. 2018. Natural antimicrobial/antioxidant agents in meat and poultry products as well as fruits and vegetables: A review. Critical Reviews in
Food Science and Nutrition, vol. 58, no. 3, p. 486-511. https://doi.org/10.1080/10408398.2016.1194256

Krishnan, K. R., Babuskin, S., Azhagu Saravana Babu, P., Sasikala, M., Sabina, K., Archana, G., Sivarajan, M., Sukumar, M. 2014. Antimicrobial and antioxidant effects of spice extracts on the shelf life extension of raw chicken meat. International Journal of Food Microbiology, vol. 171, p. 3240. https://doi.org/10.1016/j.ijfoodmicro.2013.11.011

Chan, J. T. Y., Omana, D. A., Betti, M. 2011. Effect of ultimate $\mathrm{pH}$ and freezing on the biochemical properties of proteins in turkey breast meat. Food Chemistry, vol. 127, no. 1 ,

https://doi.org/10.1016/j.foodchem.2010.12.095

109-117.

Estévez, M. 2015. Oxidative damage to poultry: from farm to fork. Poultry Science, vol. 94, no. 6, p. 1368-1378. https://doi.org/10.3382/ps/pev094

Gecgel, U., Yilmaz, I., Gurcan, E. K., Karasu, S., Dulger, G. C. 2015. Comparison of fatty acid composition between female and male Japanese quail meats. Journal of Chemistry, vol. 2015, 8 p. https://doi.org/10.1155/2015/569746

Ghazaghi, M., Mehri, M., Bagherzadeh-Kasmani, F. 2014. Effects of dietary Mentha spicata on performance, blood metabolites, meat quality and microbial ecosystem of small intestine in growing Japanese quail. Animal Feed Science and Technology, vol. $\quad 194, \quad$ p. $\quad 89-98$. https://doi.org/10.1016/j.anifeedsci.2014.04.014

Givens, D. I., Kliem, K. E., Gibbs, R. A. 2006. The role of meat as a source of $n-3$ polyunsaturated fatty acids in the human diet. Meat Science, vol. 74, no. 1, p. 209-218. https://doi.org/10.1016/j.meatsci.2006.04.008

Horwitz, W. 2000. Official methods of analysis of AOAC International. $17^{\text {th }}$ ed. Gaithersburg, Maryland, USA : AOAC International, 2200 p. ISBN-13 978-093558467-7.

Janbaz, K. H., Latif, M. F., Saqib, F., Imran, I., Zia-Ul-Haq, M., De Feo, V. 2013. Pharmacological effects of Lactuca serriola L. in experimental model of gastrointestinal, respiratory, and vascular ailments. Evidence-Based Complementary and Alternative Medicine, vol. 2013, 9 p. https://doi.org/10.1155/2013/304394

Nabavi, S. M., Nabavi, S. F., Eslami, S., Moghaddam, A. H. 2012. In vivo protective effects of quercetin against sodium fluoride-induced oxidative stress in the hepatic tissue. Food Chemistry, vol. 132, no. 2, p. 931-935. https://doi.org/10.1016/j.foodchem.2011.11.070

National Research Council. 1994. Nutrient Requirements of Poultry. $9^{\text {th }}$ rev. ed. National Academy Press, Washington, DC.

Nasr, M. A. F., Ali, E. S. M., Hussein, M. A. 2017. Performance, carcass traits, meat quality and amino acid profile of different Japanese quails strains. Journal of Food Science and Technology, vol. 54, no. 13, p. 4189-4196. https://doi.org/10.1007/s13197-017-2881-4

Nosrati, M., Javandel, F., Camacho, L. M., Khusro, A., Cipriano, M., Seidavi, A., Salem, A. Z. M. 2017. The effects of antibiotic, probiotic, organic acid, vitamin $\mathrm{C}$, and Echinacea purpurea extract on performance, carcass characteristics, blood chemistry, microbiota, and immunity of broiler chickens. Journal of Applied Poultry Research, vol. 26, no. 2, p. 295-306. https://doi.org/10.3382/japr/pfw073

Partovi, R., Seifi, S. 2018. Breast meat quality characteristics and its oxidative status during storage at refrigerator temperature and growth capabilities of Japanese quail fed by Echinacea purpurea extract. International Food Research Journal, vol. 25, no. 5, 6 p.

Reda, F. M., Alagawany, M., Mahmoud, H. K., Mahgoub, S.A., Elnesr, S. S. 2020. Use of red pepper oil in quail diets 
and its effect on performance, carcass measurements, intestinal microbiota, antioxidant indices, immunity and blood constituents. Animal, vol. 14, no. 5, p. 1025-1033. https://doi.org/10.1017/S1751731119002891

Rasul, N. R. 2020. Growth performance and microflora in growing quail fed diets supplemented with Lactuca serriola powder. Mesopotamia Journal of Agriculture, vol. 48 no. 4, p. 125-133. https://doi.org/10.33899/magrj.2020.128996.1094

Sabow, A. B. 2020. Carcass characteristics, physicochemical attributes, and fatty acid and amino acid compositions of meat obtained from different Japanese quail strains. Tropical Animal Health and Production, vol. 52, no. 1, p. 131-140. https://doi.org/10.1007/s11250-019-01991-2

Sabow, A. B., Sazili, A. Q., Aghwan, Z. A., Zulkifli, I., Goh, Y. M., Ab Kadir, M. Z. A., Nakyinsige, K., Kaka, U., Adeyemi, K. D. 2016. Changes of microbial spoilage, lipidprotein oxidation and physicochemical properties during post mortem refrigerated storage of goat meat. Animal Science Journal, vol. 87, no. 6, p. 816-826. https://doi.org/10.1111/asj.12496

Sabow, A. B., Haddad, H. S., Nakyinsige, K. 2020. Carcass characteristics and meat quality assessment in different quail lines fed on canola seed supplemented diets. Indian Journal of Animal Sciences, vol. 90, no. 1, p. 67-73.

Shirzadegan, K., Falahpour, P. 2014. The physicochemical properties and antioxidative potential of raw thigh meat from broilers fed a dietary medicinal herb extract mixture. Open Veterinary Journal, vol. 4, no. 2, p. 69-77.

Valencak, T. G., Gamsjäger, L., Ohrnberger, S., Culbert, N. J., Ruf, T. 2015. Healthy n-6/n-3 fatty acid composition from five European game meat species remains after cooking. BMC Research Notes, vol. 8, no. 1, 6 p. https://doi.org/10.1186/s13104-015-1254-1

Vargas-Sánchez, R. D., Ibarra-Arias, F. J., del Mar TorresMartínez, B., Sánchez-Escalante, A., Torrescano-Urrutia, G. R. 2019. Use of natural ingredients in Japanese quail diet and their effect on carcass and meat quality - A review. AsianAustralasian Journal of Animal Sciences, vol. 32, no. 11, p. 1641-1656. https://doi.org/10.5713/ajas.18.0800

Young, K. 2009. Omega-6 (n-6) and omega-3 (n-3) fatty acids in tilapia and human health: a review. International Journal of Food Sciences and Nutrition, vol. 60, p. 203-211. https://doi.org/10.1080/09637480903140503
Funds:

This research received no external funding.

\section{Acknowledgments:}

The authors sincerely thank the Department of Animal Resources, College of Agricultural Engineering Sciences, Salahaddin University-Erbil, Iraq for providing laboratory facilities for doing this research.

\section{Conflict of Interest:}

The authors declare no conflict of interest.

\section{Ethical Statement:}

All birds received humane care according to the standard local guidelines. The experimental protocol was approved by the local animal care and use committee of the college of agriculture engineering and science, Salahaddin University-Erbil, Kurdistan Region, Iraq.

\section{Contact Address:}

*Azad Sabow, Salahaddin University-Erbil, College of Agriculture Engineering and Sciences Department of Animal Recourses, Zanko, 44001, Erbil, Kurdistan Region, Iraq, Tel.: +9647504655099,

E-mail: azad.sabow@su.edu.krd

ORCID: https://orcid.org/0000-0003-2920-5811

Nazim Abdulla, Salahaddin University-Erbil, College of Agriculture Engineering and Sciences Department of Animal Recourses, Zanko, 44001, Erbil, Kurdistan Region, Iraq, Tel.: +9647504537027,

E-mail: nazim.abdulla@su.edu.krd

ORCID: https://orcid.org/0000-0002-5897-9966

Bestoon Ahmad, Salahaddin University-Erbil, College of Agriculture Engineering and Sciences Department of Animal Recourses, Zanko, 44001, Erbil, Kurdistan Region, Iraq, Tel.: +9647504537027,

E-mail: bestoon.ahmed@su.edu.krd

ORCID: https://orcid.org/0000-0003-2038-204

Corresponding author: * 